\title{
Industrialization and Shifting of Livelihoods
}

\author{
${ }^{1}$ M Chairul Basrun Umanailo, Sanggar Kanto, Darsono Wisadirana, Anif Fatma Chawa, Sholih Mu'adi, Ali Maksum, \\ Muhammad Lukman Hakim
}

\begin{abstract}
The conversion of agricultural land in Ngringo village was due to the entry of industry and commercial housing development that began in 1976. The orbital factor from Ngringo village to several locations such as downtown Solo, Karanganyar City and Sukoharjo attracted outsiders to come and settle by buying housing and land. empty in Ngringo village, besides the availability of various facilities such as markets, stations, schools and universities as well as health facilities make Ngringo village's location considered ideal as a settlement. Land-use change increases when the large demand for high prices for agricultural land causes landowners or farmers to be interested in selling on the assumption to increase capital or want to develop businesses outside the agricultural sector. The research is focused on the activities of informants in Ngringo village. Data analysis used the idea of Miles and Huberman where qualitative data analysis was carried out interactively and continuously. This research can show that the result of the conversion of land functions so that workers in the agricultural sector have difficulty accessing jobs. Almost all agricultural land has changed hands or ownership to the owners of capital and developers. With this condition, farmers and farm workers can no longer carry out their activities, which in turn will affect the source of income to fulfil their daily lives.
\end{abstract}

Keywords- industrialization, farm labour, land, odd jobs

\section{Introduction}

The act of changing the function of agricultural land has occurred since the existence of humans in the world (including the ancestors of the Indonesian nation) by knowing various things (objects) that are desired to maintain and obtain life satisfaction such as food, clothing, shelter and so on. However, this need continues to increase in variety, style, number and quality in line with the increasing human population. Therefore, this need means more agricultural land that needs to be changed, both in terms of function, management and ownership.

Regarding land conversion, Winoto (2005) states that five factors influence land conversion, including population factors, economic factors, socio-cultural factors, myopic behaviour (seeking short-term benefits without paying attention to long-term interests), as well as weak statutory systems and law enforcement of existing regulations. Land conversion has several negative impacts [1]. This was revealed by Sumaryanto and Sudaryanto (2005) that the negative impact of wetland conversion is the degradation of the carrying capacity of national food security, decreased agricultural income and increased poverty, waste of investment, and other negative impacts [2].

In traditional communities, the existence of land/land as a source of life is honoured and respected by the community. The relationship that exists between man and land is not only that of a person and the means of production. There is less and less respect for the land in developed farming communities [3]. The decline in the meaning of land by the community actually cannot be hindered because the development of the community itself is getting more advanced as happened in Pandeglang Regency. The community no longer thinks about the land that has traditional values in it but is more economic for them [4].

Almost all of Ngringo Village is a palur industrial area which is the largest industrial area among industrial areas located in the VIII Development Area (SWP VIII) consisting of Surakarta City, Sukoharjo Regency, Wonogiri, Klaten, Boyolali, Sragen and Karanganyar. The location of this industrial area is very strategic because it is located in a location that connects Surakarta City, Karanganyar Regency and Sragen Regency [5]-[7]. This industrial area covers five villages, namely Dagen, Ngringo, Jetis, Sroyo and Brujul Villages. In the Palur Industrial Area, there are 68 industries in the form of food, textile, plastic ore, plastic bags, plastic mats, iron plates, LPG gas, printing.

The selection of Ngringo as an industrial area was based on 2 things, namely: Transportation and Distribution; Ngringo

\footnotetext{
${ }^{1}$ M Chairul Basrun Umanailo, Ph.D Candidate, Graduate Sociology in Faculty of Social and Politic Sciences, Universitas Brawijaya, Malang, Indonesia Lecturer in Universitas Iqra Buru, Maluku, Indonesia. chairulbasrun@gmail.com Sanggar Kanto, Postgraduate lecturer in Faculty of Social and Political sciences, Universitas Brawijaya. sanggar.fisip@ub.ac.id Darsono Wisadirana, Postgraduate lecturer in Faculty of Social and Political sciences, Universitas Brawijaya. darsono_wisa@ub.ac.id Anif Fatma Chawa, Postgraduate lecturer in Faculty of Social and Political sciences, Universitas Brawijaya. anif.chawa@gmail.com Sholih Mu'adi, Postgraduate lecturer in Faculty of Social and Political sciences, Universitas Brawijaya. sholihmuadi@ub.ac.id Ali Maksum, Postgraduate lecturer in Faculty of Social and Political sciences, Universitas Brawijaya. alimaksum@ub.ac.id Muhammad Lukman Hakim, Postgraduate lecturer in Faculty of Social and Political sciences, Universitas Brawijaya.em.lukman79@ub.ac.id
} 134 
is a strategic area that facilitates distribution. This is supported by the existence of arterial roads and collector roads. This arterial road connects cities in Central Java and cities in East Java, making it easier for them to market their products to Semarang, Surabaya and Jakarta, which are the main gateways for raw materials and industrial goods that are regional, national and international. Meanwhile, the area around Ngringo Village is an area that has a lot of local workers, both from Karanganyar Regency. The Industrial Estate absorbs a lot of labour. This can be seen from the number of commuters from outside Karanganyar.

The research position in the study of land-use change in the village of Ngringo describes the condition of the community that is focused on community groups who carry out a change of function associated with someone adding/moving from agricultural to non-agricultural work. However, it is not limited to the displacement but will further study the double income pattern carried out by the community in Ngringo village, to keep fulfilling their daily needs. They no longer depend on agricultural land which is decreasing due to the need for land for infrastructure development.

\section{Design \& Analysis}

The research is focused on two things, namely; land-use change where this study seeks to describe the second change in society regarding shifts in community livelihoods. Furthermore, this research will construct the Ngringo villagers about their views and existence in the social changes that occur.

Table 1. Research Focus

\begin{tabular}{|l|l|c|}
\hline \multicolumn{1}{|c|}{$\begin{array}{c}\text { Resume } \\
\text { problem }\end{array}$} & \multicolumn{1}{c|}{$\begin{array}{c}\text { Description of Research Focus } \\
\text { Gathering } \\
\text { Techniques }\end{array}$} \\
\hline $\begin{array}{l}\text { Ecological } \\
\text { changes in } \\
\text { agricultural land } \\
\text { in Ngringo } \\
\text { village }\end{array}$ & $\begin{array}{l}\text { Transfer of land functions; } \\
\text { land conversion actions carried } \\
\text { out by landowners/farmers as } \\
\text { well as land use for economic } \\
\text { sources outside the agricultural } \\
\text { sector }\end{array}$ & $\begin{array}{l}\text { Interviews and } \\
\text { literature review }\end{array}$ \\
\hline $\begin{array}{l}\text { The profession of } \\
\text { farmers and farm } \\
\text { workers is } \\
\text { decreasing }\end{array}$ & $\begin{array}{l}\text { Shifting of Livelihoods; } \\
\text { People who used to be a farmer } \\
\text { have now changed their } \\
\text { profession (not a farmer) } \\
\text { People who used to be farmers } \\
\text { are now still farmers and have } \\
\text { other professions/jobs. The } \\
\text { survivors became farmers and } \\
\text { farm labourers }\end{array}$ & $\begin{array}{c}\text { Observation } \\
\text { and interview }\end{array}$ \\
\hline $\begin{array}{l}\text { The conditions of } \\
\text { farmworkers are } \\
\text { increasingly }\end{array}$ & $\begin{array}{l}\text { Livelihood Strategy; } \\
\text { The methods or strategies used by } \\
\text { farmers in dealing }\end{array}$ & $\begin{array}{c}\text { Observation } \\
\text { and interview }\end{array}$ \\
\hline
\end{tabular}

\begin{tabular}{|l|l|l|}
\hline difficult to fulfil & difficulties in employment and & \\
their daily needs & economic resources & \\
\hline
\end{tabular}

This study uses data analysis that combines two models, namely the case study stage and the Miles and Huberman model. Researchers analyzed data during data collection and after completing data collection within a certain period. At the time of the interview, the researcher analyzed the interviewee's answers. If the answer is not satisfactory, the researcher continues the question again until a certain stage and credible data are obtained. Activities in data analysis are carried out interactively and continue to completion so that the data is saturated. Activities in data analysis include data collection, data condensation, data display and interpretation.

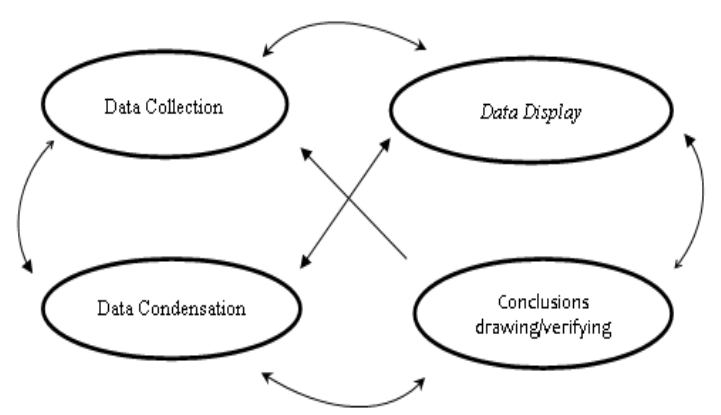

Figure 1. Interactive Model

Source: Miles, Huberman, Saldana (2014)

\section{Result and Discussion}

The land is the main production factor in agricultural business. In other words, the existence of land can be considered as a foundation in farm products that can bring job opportunities and earn rewards (income). Therefore, the system of tenure and land use management is a fairly basic socio-economic element in the development of the agricultural sector.

The results of Lean Wijaya's 2009 research on the identification of groundwater pollution using the geoelectric method in the Ngringo Jaten Karanganyar area state that there has been an overall distribution of groundwater in Ngringo village but it is uneven, pollution occurs due to contamination seepage from rivers in areas with a radius of less than $1 \mathrm{~km}$ from the river. Anindita Gangga Dewi in her research on the Socio-Economic Impact of Integrated Area Development in Pt. Gapura Mas Asri to the Community of Ngringo Village, Karanganyar Regency in 2016 stated that the impact of this development has implications for (1). Noise caused by 
vehicle traffic (both during pre-construction, construction and post-construction). (2). The flow of traffic began to be irregular. (3). Well, water disturbed by the activities of the integrated area activities. (4). Lack of job opportunities for residents. 5) The increase in the selling price of land, especially in the Ngringo Village area, due to the integrated area.

Several previous studies have shown that land is the main source where when there is a shift in land ownership it will result in a shift in other sectors in the socio-economic life of the people in Ngringo Village. The use of land as a source of income occurs due to changes in the texture of people's thinking. John Lewin Gillin and John Phillip Gillin argue that "social changes are a variation of the accepted ways of life, either because of changes in geographical conditions, material culture, population composition, ideology or because of diffusion or discoveries. in society. The direction of social change in sociology places more emphasis on the direction of change itself, meaning in which direction the change is moving. This change moves to leave behind the changed factor, but after leaving the old factor, what is the post-change state, whether it moves towards something completely new or the change moves to something that has existed in the past. In the process of its journey, change is always planned to achieve something that is considered ideal, relevant in the sense that this change is directed to meet the demands of human life.

Planned changes are always manifested in the form of development in all areas of life. Development is a set of planned and directed efforts to achieve the goal of development itself, namely achieving a better life for the community. Of course, in achieving that goal, indicators of achievement have been determined or measures of good and bad results from these changes [8]. The people of Ngringo village understand when they no longer own agricultural land and they think that land changes from time to time as the human need for land increases. This change is due to using the land for the benefit of human life. Irawan (2005) states that the change in land function will eliminate the income of farmers, both owner farmers, tenants, tenants and farm labourers who depend on farming for their livelihoods. If the conversion of land functions, especially productive rice fields that absorb a lot of labour, will decrease employment opportunities, and in turn have an impact on the income of farmers. With decreasing income, purchasing power decreases and has an impact on decreasing the economic accessibility of

Copyright $\odot$ Authors farmer households to food. However, with the entry of various new economic sources such as factories, malls and shops as well as boarding and restaurant business opportunities, the logic proposed to use the land as a source of fulfilment will be shifted as stated by Coleman that each actor will maximize the resources they have in meeting needs.

The pattern of labour use and the structure of household income in rural areas are generally still closely related to agricultural land and are strongly influenced by the condition of the agricultural land, as well as what happened to the people of Ngringo Village where the decrease in agricultural land there is relatively correlated with the availability of labour. in rural areas, the nonagricultural sector is increasingly developing and agriculture is increasingly leading to land-saving and intensive activities.

In rural areas, control of production factors generally means control of agricultural land. Especially in Ngringo Village, the definition of agricultural land is usually narrower, namely rice fields. Broadly speaking, control of production factors can be classified into landowners and non-land owners or agricultural labourers, whose level of dependence on agricultural land is very high, both in terms of employment and income [9].

Land tenure will include property rights and management/cultivation rights. Ownership rights, management rights or cultivation rights are institutional products so that their dynamics are closely related to changes in values, norms or laws that are adhered to and apply in a community. Change in ownership status can occur through buying and selling transactions, exchanges, grants or inheritance. Meanwhile, changes in management/cultivation rights occur through lease transactions, profit sharing, concession rights and so on. The study of land tenure structures can be viewed from several points of view [10]. First, is the tenure structure according to the type of land use, second, by tenure status, and third, the combination of the two types of land use is related to land suitability and the type of commodity cultivated by the population. The general phenomenon shows that most of the rural population lives from the agricultural sector. Therefore, the structure of land tenure has a close relationship with the structure of household income and employment opportunities [11].

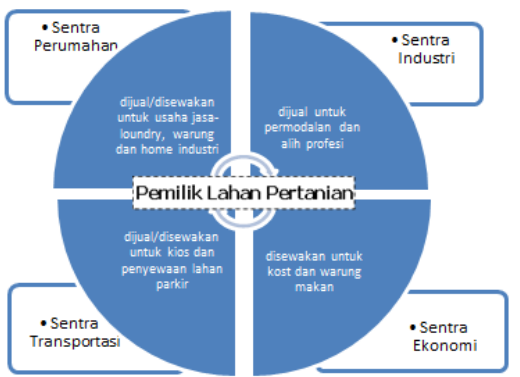

1-0595

$3-1731$ 
Matrix 1. Land use as an object of diversification

Broadly speaking, the benefits of agricultural land can be divided into 2 categories: first, use values which can also be referred to as personal use-values. These benefits result from exploitation or farming activities carried out on agricultural land resources. Second, non-use values can also be called intrinsic values. Included in this benefit category are various benefits that are created by themselves even though they are not the purpose of exploitation activities carried out by the landowner. One example is the maintenance of biological diversity or the existence of certain species, whose benefits are not known at this time, but in the future, it may be very useful to meet human needs.

The transformation of farmers' livelihood patterns in the village of Ngringo is marked by very small agricultural income, narrower arable land, large production costs are not proportional to the selling value of agricultural products, non-agricultural business opportunities are increasingly open with a large enough income, the young generation and children farmers are not willing to continue their parents' agricultural work, and there is population mobility which can result in work transactions between farmers as the party who needs work and the immigrant community as the party who needs labour. Besides, there is also a perception among the younger generation that agricultural work is considered less prestigious, seems dirty, slum, poor, less educated and does not provide a clear future guarantee.

In the view of farmers in Ngringo Village, agricultural work is not the only type of work that can generate income. Although agricultural work is very dominant in Ngringo Village, the facts show that the socio-economic life of the farming community is not only determined by the agricultural sector. Along with the increasingly open flow of information and changes like living among the community, farmers also experience changes in how they learn and behave economically in their daily lives. It is not enough to fulfil the necessities of life only by one type of work but also needs to be supported by other jobs and more productive social roles.
Activities that are carried out outside the agricultural sector are not guaranteed to get adequate income so that residents who previously worked as farmers and farm labourers like to or do not have to go out to access other professions, even though their expertise and opportunities are very limited. We can find the phenomenon that indicates that their existence is getting worse when they fulfil their daily needs. Reviewing the strongest reasons for a landowner to sell his land, namely the need and the ongoing economic process in Ngringo Village.

\section{Conclusion}

As a result of the land-use change, workers in the agricultural sector experience difficulties in accessing jobs. Almost all agricultural land has changed hands or ownership to the owners of capital and developers. With this condition, farmers and farm workers can no longer carry out their activities, which in turn will affect the source of income to fulfill their daily lives.

In a situation like this, there are several ways that are done by farmers and farm workers, namely by working odd jobs, odd jobs are work that is done not based on expertise but is closer to opportunity and uses manual labor. In carrying out these jobs, there are several norms that are intentionally maintained to carry out various jobs, such as inviting or giving information when there is work outside the village. Another strategy used is to save expenses and to do farming and raising activities in his spare time. Of all the actions taken were only economically motivated, namely the fulfillment of daily needs.

\section{REFERENCES}

[1] A. Lionardo, R. Kurniawan, and M. C. B. Umanailo, “An effectiveness model of service policy of building permit (IMB) based on a green spatial environment in palembang city," in Proceedings of the International Conference on Industrial Engineering and Operations Management, 2020.

[2] H. N. Hidayanti and R. A. Kinseng, "Konversi Lahan Pertanian dan Sikap Petani di Desa Cihideung Ilir Kabupaten Bogor," J. Sosiol. Pedesaan, vol. 01, no. 03, pp. 222-230, 2013.

[3] M. Tauchid, Masalah Agraria sebagai Masalah Penghidupan dan Kemakmuran Rakyat Indonesia. 2009.

[4] S. D. Kusdiane, E. Soetarto, and S. Sunito, "Alih fungsi lahan dan perubahan masyarakat di kecamatan cimanuk, kabupaten pandeglang,” J. Agribus. Manag., 2016.

[5] S. Kanto, D. Wisadirana, A. F. Chawa, and M. C. B. Umanailo, "Change in community work patterns," Proc. Int. Conf. Ind. Eng. Oper. Manag., vol. 0, no. March, pp. 2496-2502, 2020. A. J. Ely, A. K. Henaulu, and M. C. B. Umanailo, "Sustainable 
traditional cultural for tourism fisherier with canvas business model on the Ambon Island," Proc. Int. Conf. Ind. Eng. Oper. Manag., vol. 0, no. March, pp. 2561-2567, 2020. S. S. Fais Assagaf et al., "Construction of the village as a development shaft in the island buru," Int. J. Sci. Technol. Res., vol. 8, no. 9, 2019

[8] NN, "Perubahan Sosial Ekonomi Petani Akibat Alih Fungsi Lahan untuk Pembangunan Jalan Tol Solo-Kertosono," 2013. M. Gunawan and I. Sadikin, "Lahan Pertanian, Tenaga Kerja dan Sumber Pendapatan di Beberapa Pedesaan Jawa Barat," Forum Penelit. Agro Ekon., vol. 8, no. 1-2, p. 12, 2016, doi: 10.21082/fae.v8n1-2.1990.12-22.

[10] Muhammad Iqbal and Sumaryanto, "Strategi Pengendalian Alih Fungsi Lahan Pertanian Bertumpu Pada Partisipasi Masyarakat," Anal. Kebijak. Pertan., vol. 5, no. 2, pp. 167-182, 2007, doi: 10.1093/imanum/14.4.501.

[11] H. Bahasoan, "Pola Penguasaan Lahan Pertanian Dan Pengaruhnya Terhadap Kinerja Usahatani Padi Sawah Di Kabupaten Buru,” Media Trend, vol. 53, no. 9, pp. 1689-1699, 2013.

\section{AUTHORS}

\section{Chairul Basrun Umanailo M.Si}

Ph.D Candidate, Graduate Sociology in Faculty of Social and Politic Sciences, Universitas Brawijaya, Malang, Indonesia. has worked as a Lecturer at Iqra Buru University since 2011 until now he is still active in the University's academic activities. has served as head of the Centre for Planning and Community Development Studies (PSP2M) since 2018. Completed his master's program at Sebelas Maret University in 2016, currently

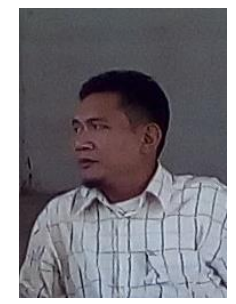
still completing a dissertation on the conversion of agricultural land functions.

\section{Prof. Dr. Sanggar Kanto MS.}

completed his undergraduate study at the Faculty of Agriculture at the University of Brawijaya in 1976, then continued his Masters in Rural Sociology of IPB and completed his S3 study in 1998 in the Social Sciences program at Airlangga University. Is the main educator in the FISIP Brawijaya post-graduate program. Have specifications on the study of demographic studies. Until now, he is still actively teaching and guiding post-graduate students of Universitas Brawijaya.

\section{Prof. Dr. Darsono Wisadirana MS}

Completed his undergraduate study at Malang Brawijaya University in 1982 and continued his Master's study at Padjadjaran University in Bandung in 1992. In 2001 he completed his S3 study at Padjadjaran University in Bandung. Have work experience such as the Cofish Project Fishermen Community Assistance Consultant - Trenggalek Regency DKP (2001 - 2005). Head of Social Sciences Program, FISIP UB (2004 - 2008) and served as Dean

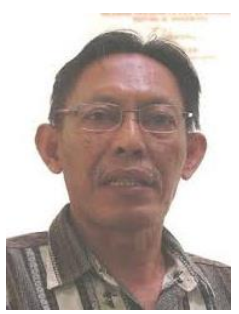
of FISIP UB in 2008. Currently, he is still actively researching; Position of Productive Workers in the Family and Urban Community Structure (2011, PNBP FISIP). Measuring Madura Hospitality (Study City Branding through the Sumenep Community Local
Wisdom Values (2013 DPP-SPP Dana Dikti) Structural and Cultural Role in Households of Independent Working Women Families in Ngantang District Malang Regency (2016. PNBP FISIP). - Culture (Local Wisdom) in Building Collaborative Harmony among Muslims (Christian-Christian) 2017, PNBP FISIP).

\section{Anif Fatma Chawa, S.Sos, M.Si, Ph.D}

is an associate professor as well as chairperson at Department of Sociology, Faculty of Social and Political Sciences, Universitas Brawijaya (FISIPUB), Indonesia. She teaches the undergraduate and postgraduate programmes at her faculty. She has supervised more than 40 undergraduate students of Sociology Study Programme, and graduate students from various study programmes including Sociology, Politic and Poverty. Studies. She graduated from the Department of Sociology of Faculty of Social and Political Sciences, Universitas Airlangga (1997) and graduate programme in Sociology (2003) Universitas Gadjah Mada (UGM). She obtained her doctorate in Community Development at College of Arts, Victoria University (VU) in 2014. She has conducted research studies concerning community development practices and presented papers in several workshops related to Corporate Social Responsibility (CSR) and Community Development conferences as well as published them. Her first research study was the implementation of community development programmes in a mining industry located in Sumbawa Island for her doctoral thesis in Victoria University, Melbourne, Australia. She has been part of the consultant team for PT. Bentoel (a giant corporate in Malang) in conducting its CSR programmes. She also studies women empowerment issues, especially in informal sectors. She employs sociological theories in various perspectives, both micro and macro perspectives in conducting her research studies and community services primarily focusing on the implementation of community development programmes.

\section{Dr. Sholih Mu'adi SH., M.Si}

is one of the lecturers at the Sociology doctoral program at brawijaya university, completing Bachelor studies at brawijaya university, continuing postgraduate studies at Gajah Mada University. Completed Doctoral Program at Diponegoro University, Semarang. Currently, there are several publications including the Plantation Land Dispute and its Settlement during the Reformation (1997-present). Settlement of Plantation Land through Nonlitigation

\section{Dr. Ali Maksum M.Si}

is a lecturer in the Sociology doctoral program at the Brawijaya University, completing his Bachelor's study at the Sunan Ampel State Islamic Institute in Surabaya, continuing his postgraduate studies at the North Sumatra State Islamic Institute and the Airlangga University, Surabaya. Completed Doctoral Program at Airlangga University, Surabaya. At present, there are several publications including Citizenship Education; Democracy, Human Rights, Civil Society, Regional Autonomy, and Multiculturalism (revised edition), Ar-Ruzz Media. Islamic liberalism and radicalism in Indonesia, Media Intelligence, 2017.

\section{Dr. M Lukman Hakim S. IP, M.Si}


is a lecturer in the Sociology doctoral program at the Brawijaya University, completed studies at the University of Muhammadiyah Malang (S1), University of Jember (S2) and S3: Airlangga University, Surabaya, Currently serves as head of the study program for doctoral sociology. actively teaching and conducting research and guiding students for master and doctoral final assignments.

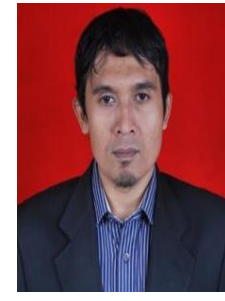

